Jpn. J. Oral Biol., $44:$ 29-39, 2002.

原著

\title{
Micro-CTを用いた下歯槽動脈の三次元的観察
}

\author{
北野良英原俊浩井出吉 信 \\ 東京歯科大学解剖学第一講座 (主任: 井出吉信教授) \\ 〔受付：平成 13 年 7 月 23 日, 受理 : 平成 13 年 10 月 31 日〕
}

\section{Three-dimensional Observation of the Distribution of the Inferior Alveolar Artery Using Micro-CT}

\author{
Yoshihide Kitano, Toshihiro Hara and Yoshinobu Ide \\ The First Department of Anatomy, Tokyo Dental College \\ (Chief : Prof. Yoshinobu Ide) \\ 1-2-2 Masago, Mihama-ku, Chiba, 261-8502, Japan \\ (Received on July 23, 2001 ; Accepted on October 31, 2001)
}

Key words : $3-\mathrm{D}$ distribution of inferior alveolar artery $/$ dental blanches $/ \mathrm{Micro}-\mathrm{CT}$

\begin{abstract}
The purpose of this study was to clarify the distribution of the inferior alveolar artery (IAA) and its dental branches in the mandibular canal and surrounding tissues in both dentulous and edentulous mandibles using a Micro-CT system.

Twenty-six sides of 18 mandibles from Japanese cadavers were examined. Contrast medium was injected into the maxillary artery of the examined specimens to obtain the Micro-CT and 3-D reconstruction images. Maximum vertical length and horizontal breadth of the mandibular canal were measured to determine the position of IAA in the canal. The angle of the dental branches against IAA and the inside diameter of IAA were also examined.

The vertical position of IAA in the molar area was higher in the edentulous than that in the dentulous mandible. There was, however, no significant difference in the horizontal position. The retromolar ramus, in which the dental branches were distributed at the retromolar region, was usually observed to run toward the buccal just after separating from IAA. The inside diameter of IAA was smaller in the edentulous than that in the dentulous mandible.

These results suggest that positional change of IAA in the mandibular canal and decrease of inside diameter may be caused by absorption of alveolar bone following tooth loss and subsequently morphological change of the mandibular canal. However, the running direction of the retromolar ramus did not change.

抄録：有歯顎と無歯額における下歯槽動脈の走行形態および歯枝の分岐形態を把握することを目的として, Micro-CT 用いた三次元的観察および解析を行った。試料として䫟動脈より造影剤の注入を行った日本人成人 遺体 18 体 26 側を用いた。下顎管を基準とした下歯槽動脈の垂直的位置, 水平的な位置, 血管内径および下歯槽 動脈を基準とした歯枝の分岐する角度の計測を行ったところ，以下の結果を得た。下顎管内部における下歯槽動
\end{abstract}

テ 261-8502 千葉県千葉市美浜区真砂 1-2-2 


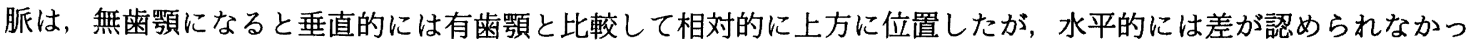
た。血管内径は無歯顎になると細くなる傾向が認められた。歯枝は歯牙の亦失により分岐する数の減少がみられ たが，臼後領域に向かう臼後枝は变化が認められなかった。また，その臼後枝は煩側方向に分岐していた。これ らは，歯牙喪失による歯槽骨の吸収，それに伴う内部構造，特に下顎管の構造の変化が大きく関与していた。

緒言

下歯槽動脈の走行分布は下顎骨の成長発育や病態と深 くかかわっており，それを把握することで下頸骨内部に 及ぶ処置の際, 術中の危険性を減少できると考えられる。

下歯槽動脈は下顎骨の内部を走行しているため, その 走行を検索するには骨を除去して行う肉眼的観察 ${ }^{1-3)}$ や, $\mathrm{X}$ 線写真を用いた観察 ${ }^{4,5)}$, 透明標本による観察 ${ }^{6)}$, 病理組 織標本による観察 ${ }^{7-15)}$, 鋳型標本を用いた SEM 像の観 察16-20)などさまざまな方法がこれまでに用いられてき た。しかし、これらの観察方法はいずれも試料に対する 破壊や変性が不可避であり, しかも特定の断面からの観 察を余儀なくされるため, 立体的な構造を把握しにくい という久点があった。Oikarinen ${ }^{4}$ が Stereoorthopantomoarteriogram を用いて, 下顎骨内部の下歯槽動 脈の走行形態と歯枝の分岐状態を加噛的変化とあわせて 報告し，そのなかで歯枝のうち臼後領域に向かうものを retromolar ramus（臼後枝）として分類した。しかしな がら, 三次元的に下歯槽動脈の走行を表現しているとは いい難く，下顎管との位置関係については不明確である といわざるを得ない。

ところで, 近年, 極微小焦点 X 線 CT 装置（以下, Micro-CT) が開発され, 骨や歯牙の研究を中心に応用さ れるようになってきた ${ }^{21-24)}$ 。Micro-CT は非破壊的に高 解像度で顎骨内部の三次元的な観察および定量的解析が 可能であり, 形態観察の一方法として有効である ${ }^{21-24) 。}$ 下歯槽動脈の観察においても造影剤を注入することでそ の形態を保存したまま, しかも非破壊的に任意の断面観 察を行うことが可能である。

そこで造影剤注入標本を作製し，Micro-CT を用い て, 下歯槽動脈の下顎管内部での立体的な走行形態およ び下㴿骨における歯枝の分岐状態の観察をした。また, 歯牙の喪失による下歯槽動脈および歯枝の走行形態の変 化を把握するために, 有歯顎と無歯顎での比較検討も 行った。

\section{材料および方法}

研究材料は, 造影剂注入済み未固定新鮮日本人成人遺
体より摘出した下顎骨 18 体 26 側 (有歯顎 8 体 11 側, 無 歯靧 10 体 15 側)を用いた (Table 1)。なお，中切歯より 第 2 大臼歯までが残存しており，咬頭嵌合位を保ってい るものを有歯顎とした。

\section{1. 標本作成および撮影方法}

下歯槽動脈を Micro-CT で観察するために動脈内部 に造影剤を注入した。造影剤は $65^{\circ} \mathrm{C}$ に加温した蒸留水 $100 \mathrm{~m} l$ に対して硫酸バリウム $80 \mathrm{~g}$ を加え, 添加剂とし てゼラチンを $8 \%$ の濃度になるように加えた ${ }^{25)}$ 。次いで, 両側の顎動脈より毛細血管および静脈に造影剤が入らな いよう注意しつつ, 造影剤を約 $120 \mathrm{mmHg}$ の圧で注入し た。注入後, $10 \%$ ホルマリン中に浸漬させ固定を行うと 同時に, 冷却して造影剂を硬固させた後, 造影剤が硬固 した下顎骨を摘出し, Micro-CT で撮影を行った。

撮影する際の試料の位置付けは, 試料の下顎下縁平面 と試料ステージが垂直になるよう設定した（Fig. 1)。撮 影は, 管電圧 $70 \mathrm{kV}$, 管電流 $100 \mu \mathrm{A}$, 撮影倍率 1.2 倍の 条件下で行った。撮影で得られた Raw dataを簡易型多 断層面構築ソフト (MultiBP, Imagescript) によりスラ イス画像データ 900 枚を再構成した。フォトレタッチソ フト(Photoshop, Adobe)を用いて, 各スライス画像の ノイズ除去, コントラストの調整を行った。さらに三次 元立体構築ソフト (Vox Blast, Image\&Measurement) を用いて立体像の再構築を行った。

\section{2. 観察部位}

下歯槽動脈の走行を有歯顎と無歯顎で比較するために Micro-CT で得られた下顎骨外形像を用いて, 下頡孔よ

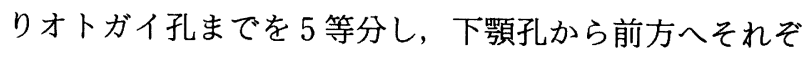
れ $\mathrm{A}$ 部， B 部， C 部， D 部， $\mathrm{E}$ 部と設定した (Fig. 2)。 また， A 部の遠心断面から下頡孔部断面(以下, $\mathrm{a}$ 断面), 下顎枝前縁部断面 (以下, $\mathrm{b}$ 断面), 第 3 大臼歯相当部断 面 (以下, $\mathrm{c}$ 断面), 第 2 大臼歯相当部断面 (以下, $\mathrm{d}$ 断 面), 第 1 大臼歯相当部断面 (以下, e 断面) と断面を設 定した (Fig. 2)。

\section{Micro-CT 像の観察}

再構築を行った下歯槽動脈本幹の像を立体的に観察 し, 有歯顎と無歯顎で比較を行った。 
Table 1 Materials

\begin{tabular}{ccccc}
\hline \multicolumn{2}{c}{ dentulous } & & \multicolumn{2}{c}{ edentulous } \\
\cline { 1 - 2 } \cline { 5 - 5 } No. & Age & & No. & Age \\
\hline 1 & 57 & 9 & 65 \\
2 & 58 & & 10 & 69 \\
3 & 59 & & 11 & 72 \\
4 & 64 & & 12 & 72 \\
5 & 67 & & 13 & 75 \\
6 & 73 & & 14 & 76 \\
7 & 74 & & 15 & 76 \\
8 & unknown & 16 & 77 \\
& & 17 & 80 \\
& & 18 & unknown \\
\hline
\end{tabular}

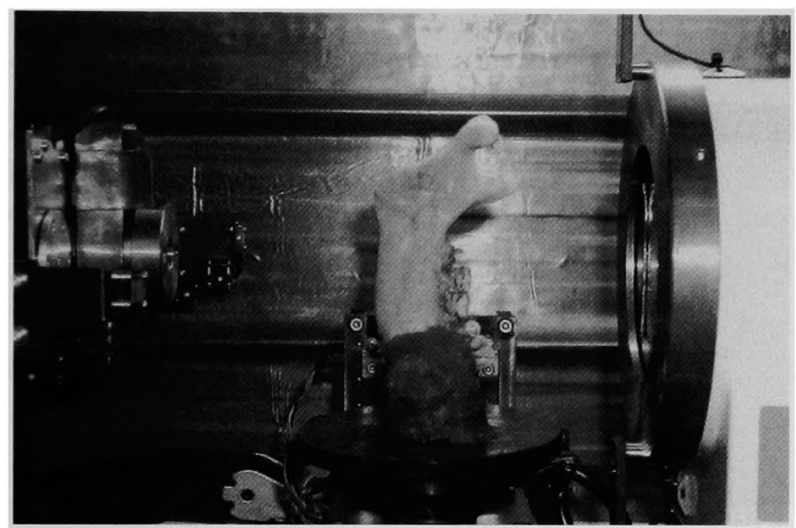

Fig. 1 The material placed in Micro-CT device.

\section{4 、下顎管に対する垂直的，水平的位置関係}

下歯槽動脈の下顎管内部での位置関係を把握するため に上記 5 断面での下歯槽動脈の垂直的，水平的位置，角

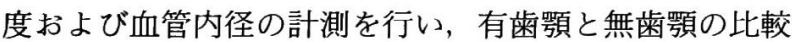
を行った。

\section{1 ）下顎管内での垂直的位置関係}

上記 5 断面に扔ける下歯槽動脈の下靧管下壁からの位 置をミリメートル単位で表した。また，下顎管の最大上 下径に対する下歯槽動脈の中心の垂直的位置を下顎管下 壁から計測し，百分率で表した (Fig. 3-a)。

\section{2）下顎管内での水平的位置関係}

上記 5 断面における下歯槽動脈の下顎管煩側壁からの 位置をミリメートル単位で表した。また，下顎管の最大 幅径に対する下歯槽動脈の中心の水平的位置を下顎管㥧 側壁から計測し，百分率で表した (Fig. 3-b)。

3 ）歯枝の立ち上がる角度

歯枝の分岐形態を把握するために分岐部位での下歯槽 動脈本幹を基準にして，歯枝の立ち上がる角度を矢状断
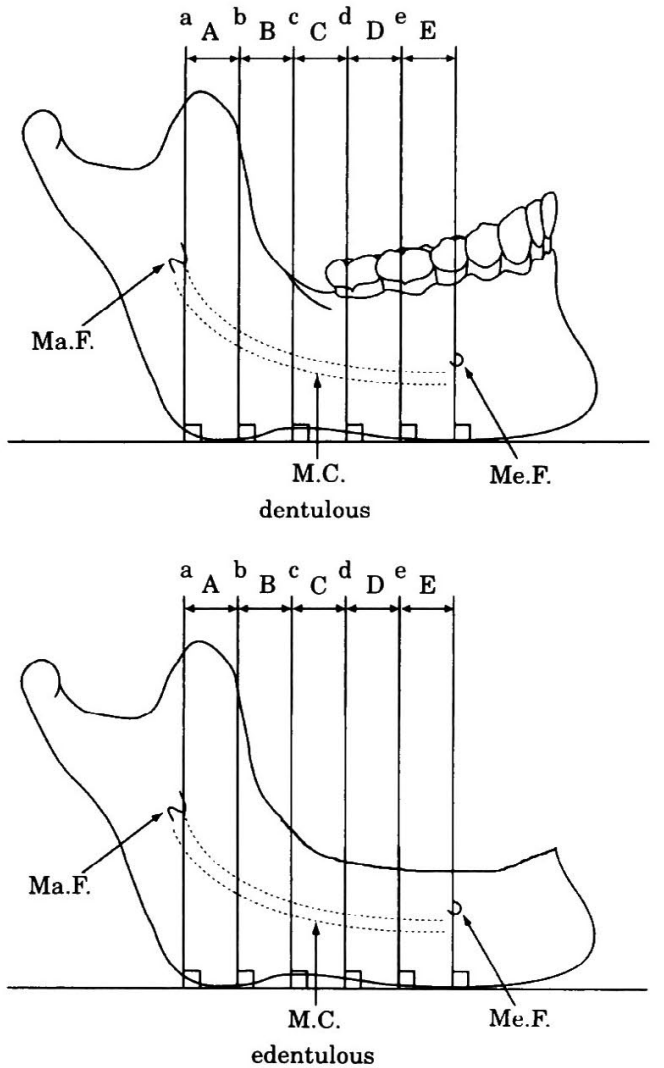

Fig. 2 Regions observed by two dimensional and three dimensional methods.

Ma. F. : mandibular foramen, M. C. : mandibular canal, Me. F. : mental foramen.

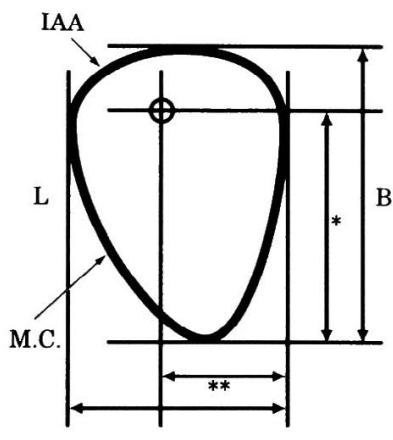

a

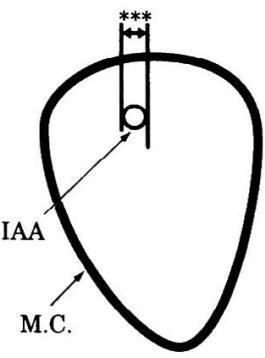

b
Fig. 3

a : Positional relationship between IAA and mandibular canal, b : Inside diameter of IAA.

* : Distance between lower wall of mandibular canal and IAA, $* *$ : Distance between buccal wall of mandibular canal and IAA, $* * *$ : Inside diameter.

$\mathrm{B}$ : buccal side, L : lingual side, M. C. : mandibular canal, IAA : inferior alveolar artery. 


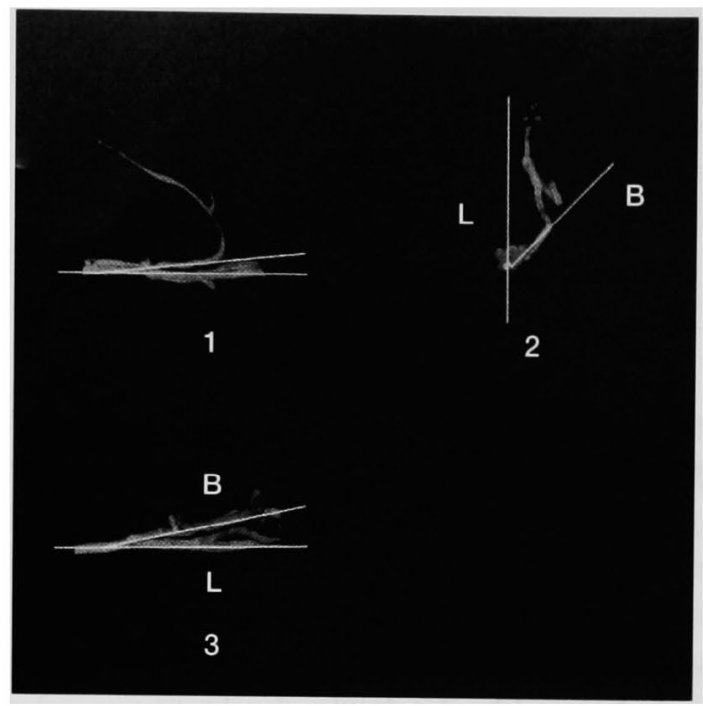

Fig. 4 Angle of dental branches against IAA. 1 : sagittal plane, $2:$ buccolingual plane, $3:$ horizontal plane.

方向, 煩舌断方向, 水平断方向の 3 方向から計測した (Fig. 4)。

4 ）血管内径

上記 5 断面における下㠝管中を走行する下歯槽動脈の 血管の煩舌径を計測し，ミリメートル単位で表した(Fig. 3-a, 3-b)。

5 ) 統計学的取り扱い

統計処理により, 平均値, 標準偏差を求めた。また, 平均值の有意差は有歯靧と無歯頡間について $\mathrm{t}$ 検定 $(5 \%$ 水準）により求めた。

\section{結果}

\section{Micro-CT 像の観察}

下歯槽動脈本幹の位置は有歯顎, 無歯頡ともに下顎孔 部で下顎管に対して上下的にほほ中央付近に，煩舌的に は煩側寄りに観察された (Fig. 5)。その位置は A 部内, すなわち下顎枝部内に扔いて下顎管の上部に移行してい た。 $\mathrm{B}, \mathrm{C}$ 部内での下顎管に対する位置は下頡管の上壁に 近接していた。 $\mathrm{D}$ 部内の下歯槽動脈本幹は下顎管を上下 的に蛇行していた。E 部内では, 舌側方向に走行方向を変 えオトガイ孔から出る枝と前方に向かう枝に分岐してい た (Fig. 6)。

臼後枝は下顎枝で煩側方向に分岐し，下歯槽動脈本幹 の上部を並走し，下顎管上壁から出た後もさらに前走し ていた。第 2 大臼歯部の手前で臼後領域に向かって鋭角
に方向を変えていく様子が観察された。この臼後枝は無 歯頡においても同様に観察された。また，臼後枝から分 岐し前方の大自歯や歯槽骨に分布している枝も観察され た。大臼歯部の後方からは数本の歯枝が大臼歯や周囲の 歯槽骨に向かって斜めに立ち上がり，その走行は煩側方 向に立ち上がるものや舌側方向に立ち上がるものとがあ り，不定であった。また，立ち上がる際に下顎管中で下 方に分岐した後に上方にいくものもみられた。無歯靧で は分岐する枝の本数は有歯顎と比較して隇少し, 血管径 が細くなっている傾向であった（Fig. 7，8）。

\section{2. 下顎管に対する垂直的，水平的位置関係}

1 ） 下頷管内での垂直的位置関係

下䋶管下壁からの距離は c， d 断面ともに有歯影より も無歯顎のほうが若干減少している傾向がみられたが, 有意差は認められなかった（Fig. 9)。下顎管の最大上下 径に対する下歯槽動脈の垂直的位置は $\mathrm{c}, \mathrm{d}$ 断面ともに 有歯顎よりも無歯顎のほうが割合を増加させており，有 意差が認められた。つまり, 有歯㖽と比較して無歯顎で は下顎管内で相対的に高い位置を走行していた(Fig. 10)。

2 ）下顎管内での水平的位置関係

下顎管舌側壁からの距離は a , b , c , d, e 断面のすべ ての部位において有歯顎と無歯顎との大きな差は認めら れなかった(Fig. 11)。また，下顎管の最大幅径に対する 下歯槽動脈の水平的位置は $\mathrm{a}, \mathrm{b}, \mathrm{c}, \mathrm{d}, \mathrm{e}$ 断面のすべて において有歯頡と無歯顎間で大きな差が認められなかっ た (Fig. 12)。

3 ）臼後枝の立ち上がる角度

臼後枝は, 矢状断面からみると, 分岐する際に約 10 度 の角度をもって上方に分岐していた (Table 2)。煩舌断面 および水平断面からこれをみると, いずれも煩側に向 かって分岐していた（Fig. 7)。有歯顎と無歯頡には臼後 枝が立ち上がる角度に有意な差が認められなかった。

4 ）血管内径

下歯槽動脈は有歯顎, 無歯顎ともに下預孔からオトガ イ孔に向け前走するに従い,血管の内径が減少していた。 a, b 断面間, c, d 断面間で急激に血管の径を減少してお り，有意差が認められた。また，a，b，c，d，e断面にお ける下歯槽動脈の内径はすべての部位において, 有歯顎 よりも無蒾顎のほうが減少する傾向がみられ, 有意差が 認められた (Fig. 13)。 


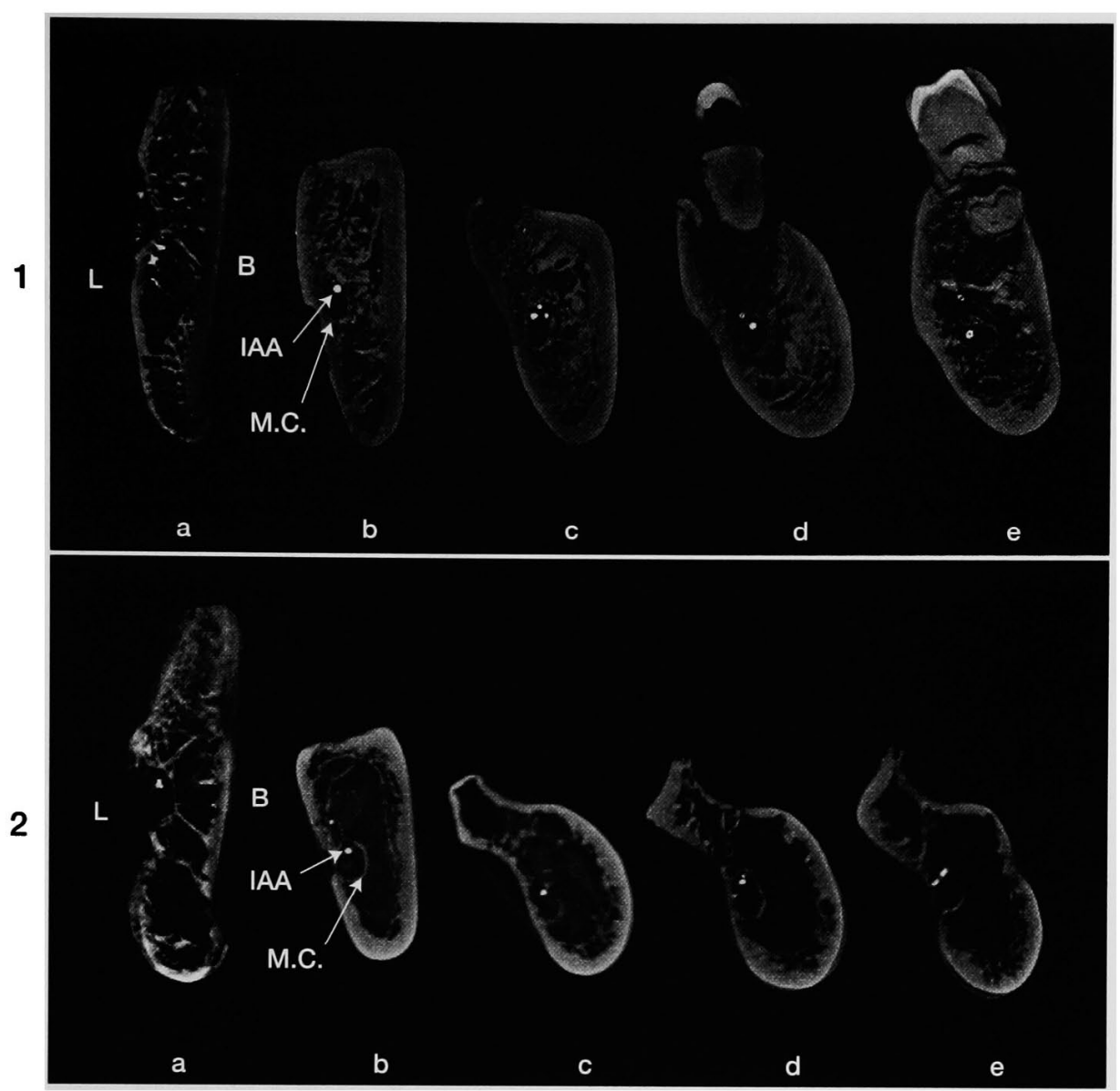

Fig. 5 Sliced images taken by Micro-CT systems.

$1:$ dentulous, 2 : edentulous.

B : buccal side, L : lingual side, M. C. : mandibular canal, IAA : inferior alveolar artery.

考察

\section{1. 観察方法について}

下顎骨内部の下歯槽動脈の走行形態を観察する方法と して, Oikarinen ${ }^{4}$ は動脈内にバリウム造影剤を注入し, Stereo-orthopantomoarteriogram で観察した。この方 法は, 臨床上使用頻度の高いパントモ像での下歯槽動脈 の走行形態を知るうえで有効であると考えられるが，二 次元的な像であり，下顎管内部での煩舌的な位置関係を はじめとする周囲組織との三次元的な位置関係を把握す ることが困難である。

Poirot $ら^{1)}$ は動脈内に色素含有合成樹脂を注入し, 皮 質骨を除去後, 剖出し血管鋳型標本の観察を報告した。 この方法は, 合成樹脂の硬度と骨梁内部の神経との判別
が可能になることで観察が比較的容易になる利点をも ち, 三次元的な観察が可能である。しかし, 周囲組織の 除去が不可避であるため破壊的であり, 骨との煩舌的な 位置関係の把握が困難である。

Micro-CT 用いた観察は従来の X 線像を用いた観 察とは異なり，スライスデータをもとに再構築している ため任意の断面での観察が可能である。そのため, 血管 鋳型標本のように立体的な走行形態の把握を容易にし, 従来の方法では観察できなかった頓舌断面からの歯枝の 立ち上がりについて観察することを可能にした。また， 皮質骨の除去など剖出操作を伴わないことから破壊せず に下歯槽動脈と周囲の骨組織, 特に下顎管との位置関係 の観察には有効であることが示唆された。

Micro-CT は X 線を用いるため, 血管の走行を知るに は前操作として造影材の注入操作が必要となるが, 血管 


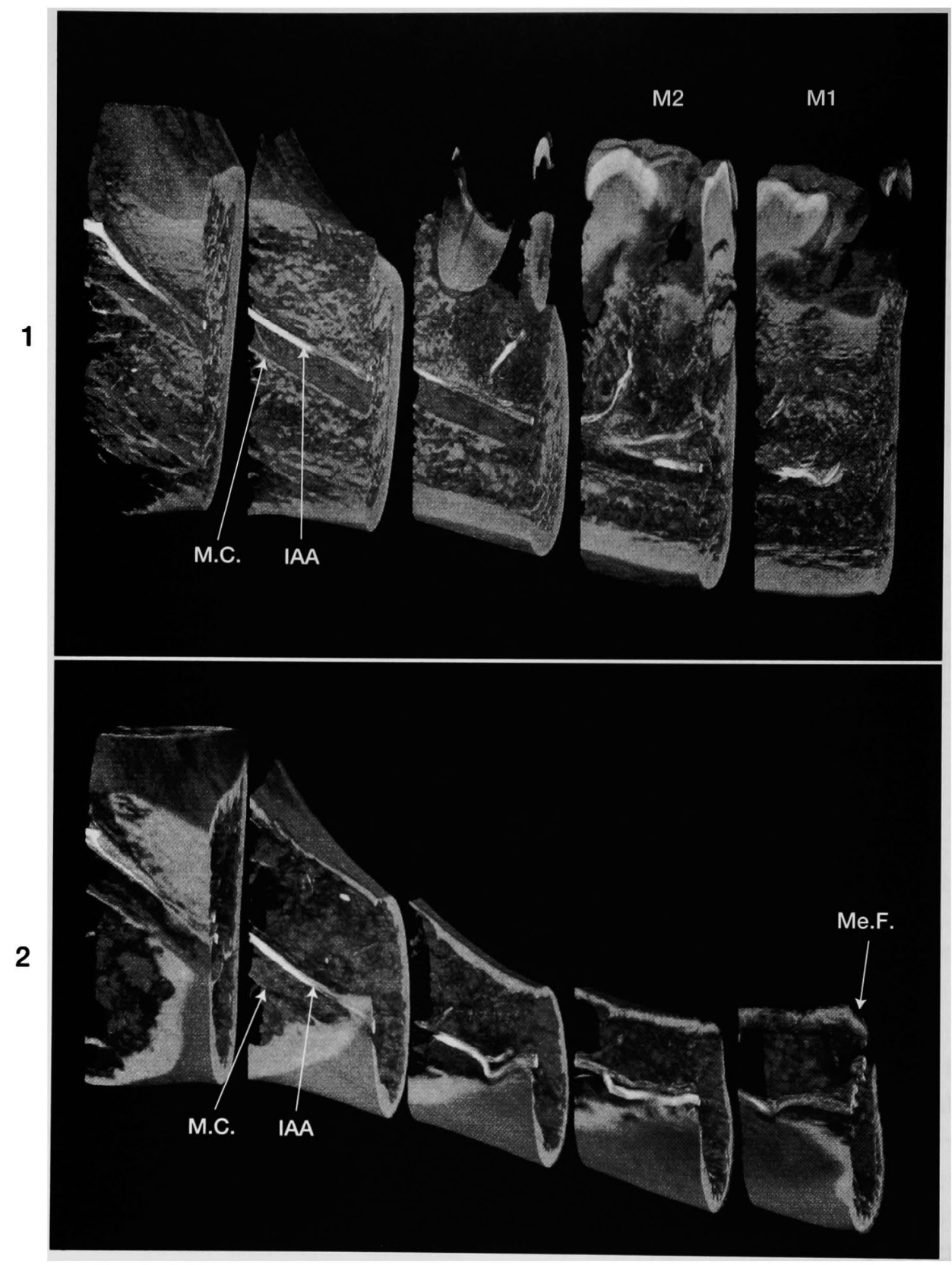

Fig. 63 -D reconstruction images of IAA sliced along the mandibular canal. $1:$ dentulous, 2 : edentulous.

M. C. : mandibular canal, IAA : inferior alveolar artery. Me.F. : mental foramen, M 1 : first molar, M 2 : second molar.

と周囲組織の位置関倸や血管壁に及ほす影響を少なくす るため, 注入圧を約 $120 \mathrm{mmHg}$ とした ${ }^{25)}$ 。また, 胎児の 聴覚器の小動脈を Microfocus X-ray CT で観察した Shibata ら ${ }^{21)}$ は, 造影剤にバリウムを用いると描出能が 優れていたと述べているため, 本研究でもバリウムを採 用した。その結果, 血管破壊の少ない像であった。

\section{2.下歯槽動脈本幹の走行について}

猪鹿倉 ${ }^{26)}$ は下顎孔入口部における脈管，神経の位置的 関係を 16 型に分類し, 下顎孔の前半部は下歯槽神経が, 後半部には下歯槽動静脈が位置し, 動静脈はいずれか一 方が内側または動脈が静脈より前方位に位置するものが 多いと述べている。今回の標本でも神経の後方から進入 


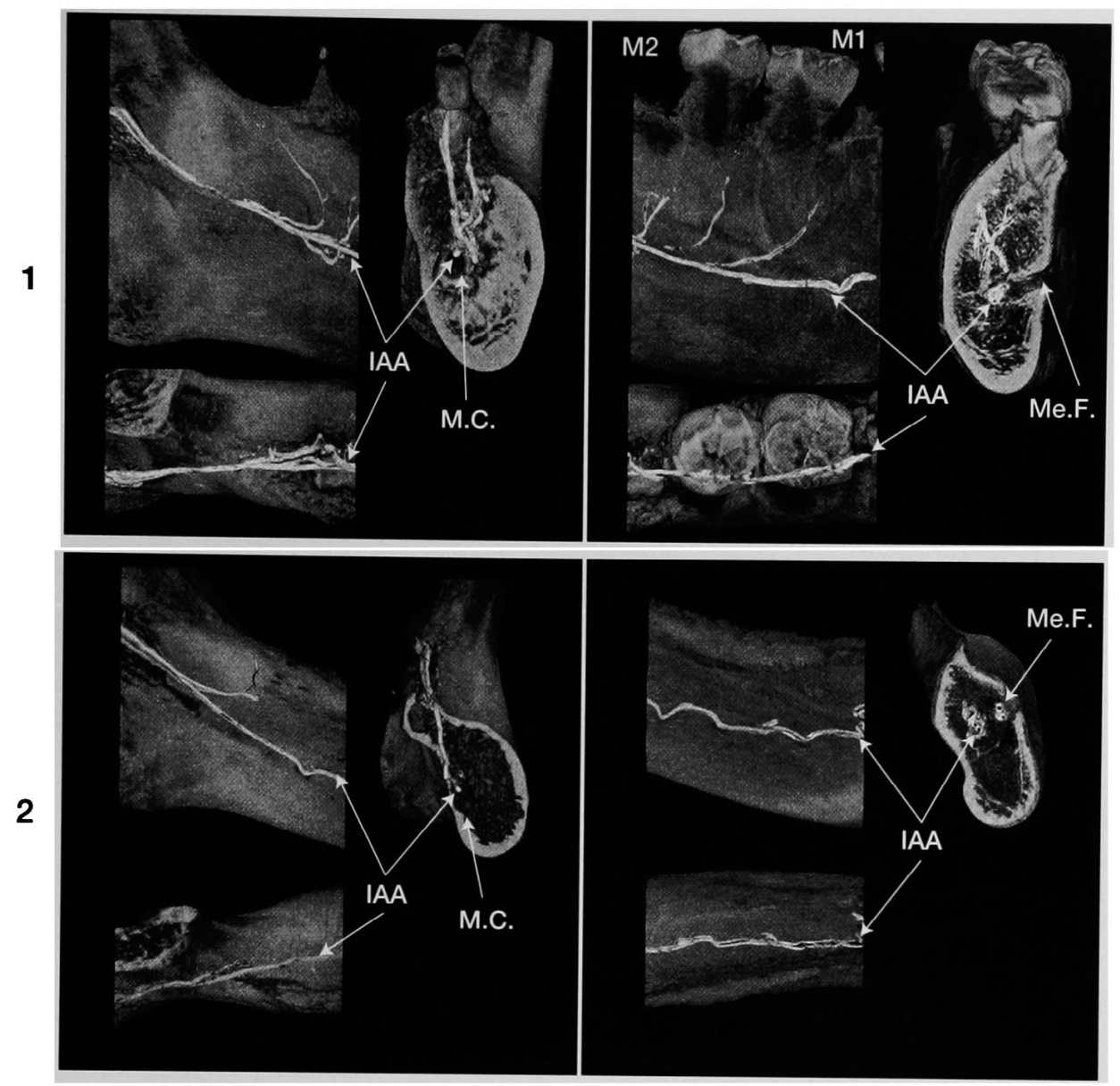

Fig. 7 3-D reconstruction images of dental branches.

$1:$ dentulous, 2 : edentulous.

M. C. : mandibular canal, IAA : inferior alveolar artery. Me. F. : mental foramen, M 1 : first molar, M 2 : second molar.

するものが多かったものの, 神経の内側もしくは前方か ら進入していたものが $42 \%$ みられた。また, 下顎孔部で 下顎管の中央付近に位置していた下歯槽動脈本幹は, 大 臼歯部に向かう間に位置を上方に変え, 第 1 大臼歯部付 近からは上下的に蛇行をしながら走行している像が観察 された。本研究でみられた $\mathrm{a}, \mathrm{b}, \mathrm{e}$ 断面の垂直的位置の ばらつきは，これらのことに起因すると思われた。d, e 断面, すなわち第 3 大兒歯相当部と第 2 大臼歯相当部に おける下顎管内の下歯槽動脈の垂直的位置関係は, 有歯 頱より無歯顎で下顎管下壁に対して若干低い位置を走行 するものの, 相対的には有歯顎のほうが低い位置を走行 している傾向がみられた。これは歯牙の喪失に伴って歯 槽部の吸収が起こることにより，下顎管の特に上壁の形 態が円形に近い形態に変化していく ${ }^{27)}$ たであると考え られた。また，下歯槽動脈の水平的位置関係が有歯顎と
無歯顎ともに差がみられなかったのは, 歯牙の喪失によ る下顎管の水平的な形態変化が少ない27ためであろう。

下簤骨は歯牙の喪失に伴い, 歯槽骨の吸収とともに内 部構造にも変化を起こすことが報告されている28-31)。さ らに, 下顎管内部の下歯槽神経, 動, 静脈の位置関係に も影響を及ほし，無歯顎症例ではインプラントなどの下 䪽骨内部に及ぶ処置の際に下歯槽動脈が下頡管のより上 方に位置することを留意する必要があると考えられた。

\section{3. 歯枝の分岐状態について}

Zoud ら²は下顎管のなかにおいて下歯槽神経血管叢 と表現すべき複雑な形態をしていると報告している。実 際, 下顎管のなかでは下歯槽神経, 動, 静脈と併せてそ の分枝が複雑に走行していた。Poirot ら'が報告してい るように, 下歯槽動脈から分岐する枝を歯牙や歯槽骨に 


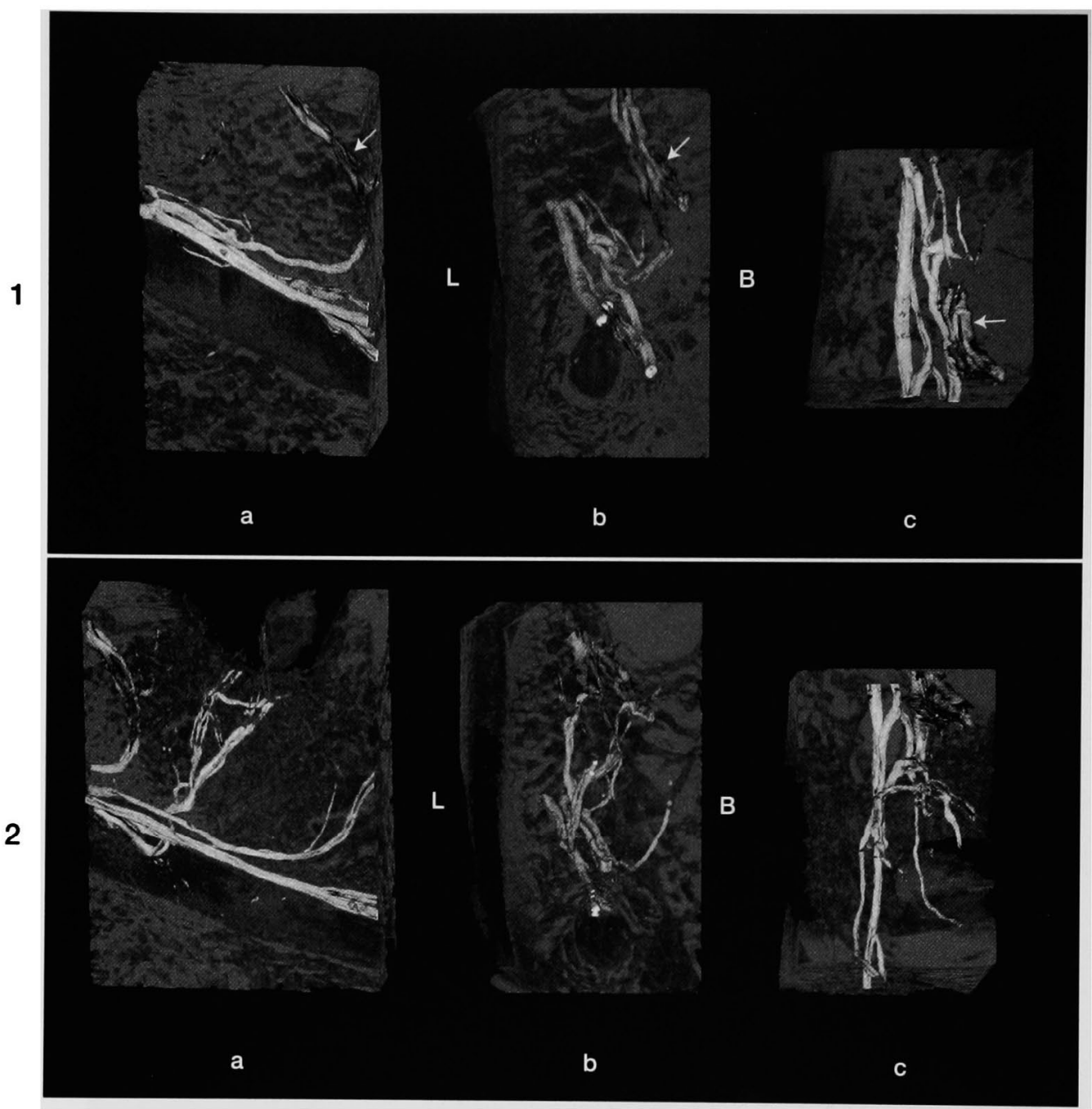

Fig. $83-\mathrm{D}$ reconstruction images showing the direction of dental blanches against IAA. 1 : retromolar ramus, $2:$ dental blanches.

a : sagittal plane, b : buccolingual plane, $\mathrm{c}$ : horizontal plane. $\mathrm{B}:$ buccal side, $\mathrm{L}:$ lingual side, $\leftarrow$ : retromolar ramus.

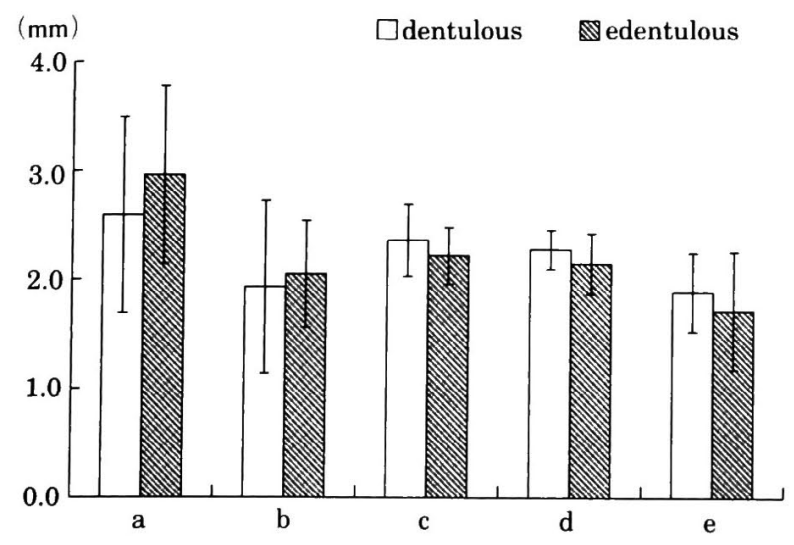

Fig. 9 Distance between lower wall of mandibular canal and IAA.

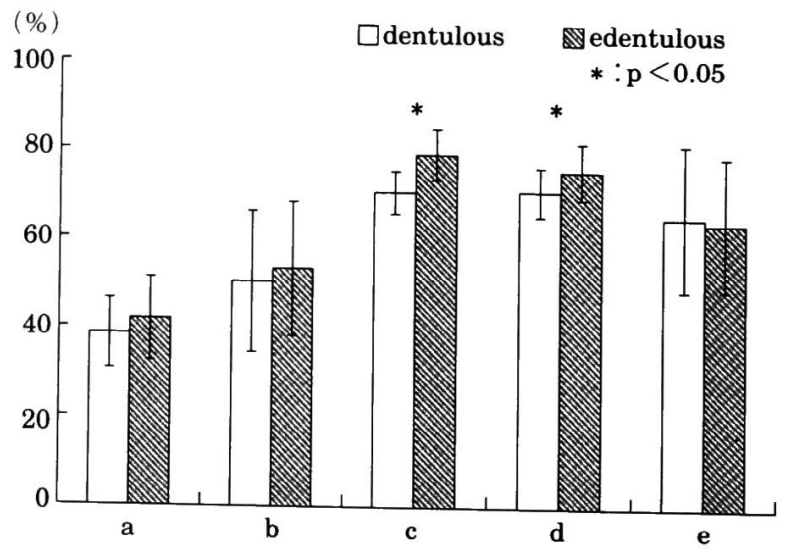

Fig. 10 Vertical position of IAA in mandibular canal. 
分布する principal collaterals と神経血管鞘や底部の骨 に分布する非常に細い secondary collateralsに分類す ると, 下歯槽動脈の本幹が下䫟孔からオトガイ孔まで 1 本の動脈として走行しているのがわかる。下顎角部から 分岐する principal collaterals は主に臼後部に，もしく はさらに分岐して大臼歯に分布し, 下顎体部から分岐す る枝は分岐した場所から前方の歯牙に分布するとしてい る。また, Oikarinen ${ }^{4)}$ は下歯槽動脈本幹から分岐した後, 第 3 大臼歯部付近で鋭角に走行方向を変え下䫇枝前方の retromolar regionに分布する枝を retromolar ramus とし, 147 側中 79 側あったとしているが, 統計学的に年

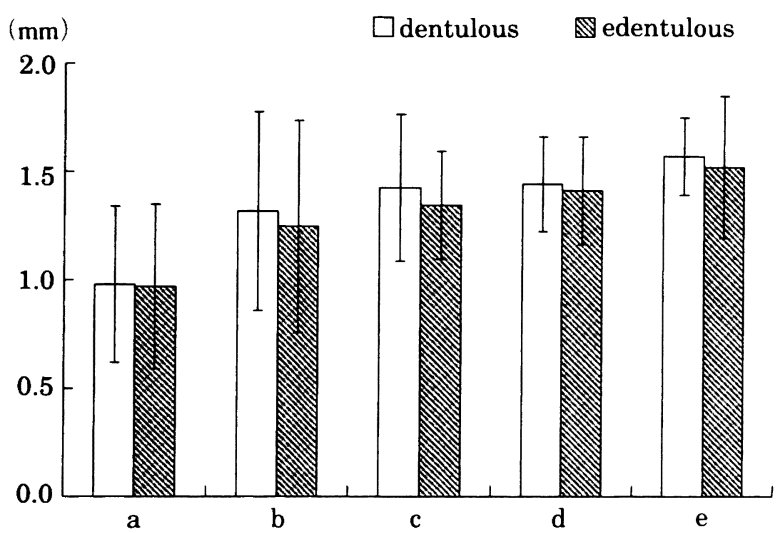

Fig. 11 Distance between buccal wall of mandibular canal and IAA.

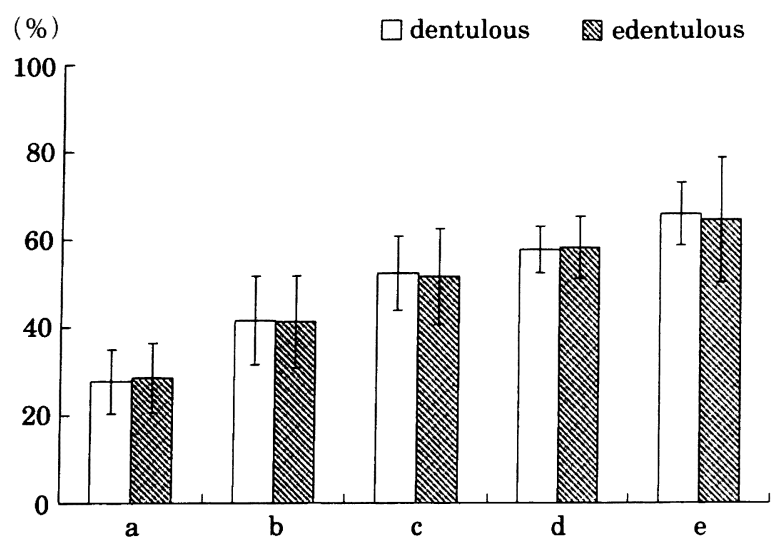

Fig. 12 Horizontal position of IAA in mandibular canal.
齢との相互関係はみられなかったとしている。小寺ら は，臼後管を走行する神経扔よび血管について観察を 行ったなかで，臼後管の出現率は $19.5 \%$ ，開孔部位は第 3 大臼歯の遠心部だとしている。

著者は，歯牙や歯槽骨に分布する歯枝を対象として観 察を行い，有歯顎では同様の所見を得た。無歯頡では下 顎枝部で分岐して臼後部に向かう枝は有歯顎と大差はみ られなかったが，臼歯部に向かい立ち上がる歯枝では細 く数が少なくなる傾向がみられた。このことは臼歯部で は歯牙の喪失に伴う歯槽骨の吸収により下顎管の上壁の 小孔が少なくなる27)ことに密接に関係していると考えら れた。

臼後枝は 26 例中すべてのものにみられたが, 臼後管と いうはっきりした管腔構造は認められなかった。本研究 の倍率は 1.2 倍という弱拡大であったため, 臼後管の走 行を把握できなかったと考えられた。しかし今回, Micro-CT を用いたことで, 従来の方法では観察できな かった煩舌断面での歯枝の立ち上がりについて把握する

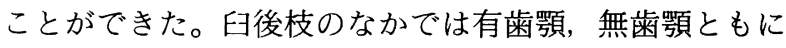
煩舌的に煩側方向に立ち上がっていくものが大勢を占め た。これはその部位の下顎管が舌側に位置している ${ }^{27) こ ~}$ とに起因していると考えられた。

\section{4. 下歯槽動脈の血管内径について}

下歯槽動脈の経年的変化について, Bradley ${ }^{7,8)}$ は動脈

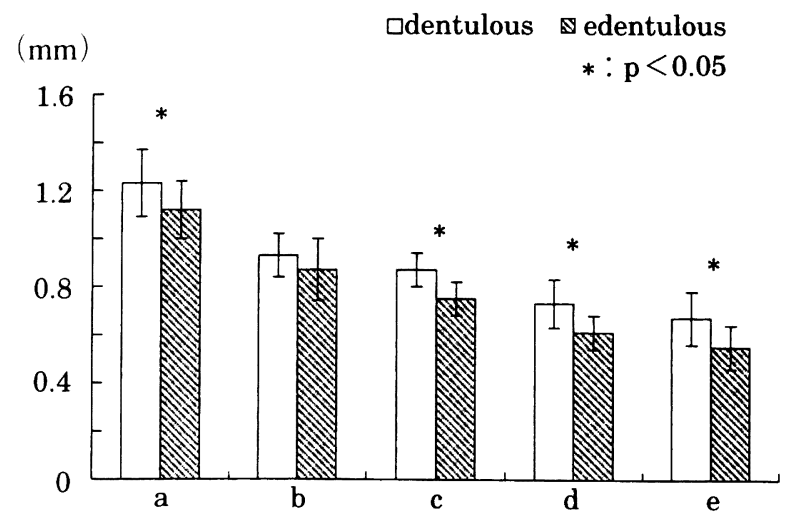

Fig. 13 Inside diameter.

Table 2 Angle of retromolar ramus against IAA

\begin{tabular}{cccc}
\hline & sagittal plane & buccolingual plane & horizontal plane \\
\hline dentulous & $11.2( \pm 4.2)$ & $43.3( \pm 7.3)$ & $16.7( \pm 2.2)$ \\
edentulous & $10.3( \pm 2.9)$ & $41.8( \pm 5.7)$ & $14.5( \pm 5.6)$ \\
\hline
\end{tabular}

Unit : degree (S. D.) 
硬化症の結果として加柃的に動脈が狭窄していくと報告 している。歯槽膿漏症による䫟骨吸収と下歯槽動脈硬化 症との関連性について, 佐藤 ${ }^{13)}$ は下歯槽動脈の主管の硬 化性変化は若年者に必発の所見ではないことから増齢に 伴う変化であるとし，細枝の硬化像は年齢との関連性よ りも顎骨吸収度と強い平行関係があると報告している。 浦郷ら ${ }^{11}$ は下歯槽動脈の組織学的観察では, 主管, 細枝と も 20 歳台前半を過ぎる頃から弾性線維増生を主とする 硬化性変化が認められるようになり, 加路とともに内弾 性板の重複, 内膜や中膜の線維増生を伴う内膜肥厚, 内 腔狭窄が強くなるとしている。そのために歯牙が喪失す ると歯牙に分布していた細枝とその周囲の歯槽骨内に分 布していた細枝が消失するために，歯枝の本数の減少， さらには下歯槽動脈本幹の血管内径の細くなる傾向がみ

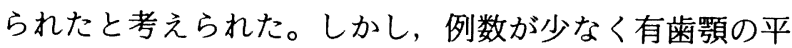
均年齢が 64.5 歳, 無歯頜が 73.5 歳であったため, 年代 間の検討を併せて行えなかったので加齢的変化について は検討すべき点を残した。しかし，御手洗ら ${ }^{32}$ は, 後上歯 槽動脈の血管内径を計測し，有歯顎と比較して無歯領で は, 各年代において細くなる傾向がみられ, 加齢的な要 因よりも歯牙の喪失による影響のほうが大きいとしてい ることから, 下歯槽動脈の狭窄についても同様に，加齢 的要因よりも歯牙の有無が関与していると想起された。 これらのことから, 有歯顎と比較して無歯顎では歯枝の 本数が減少し, 下歯槽動脈本幹の血管内径が細くなる傾 向が認められたのは，歯牙喪失に伴う歯槽骨の吸収によ り末梢における血流量が減少するためではないかと考え られた。

\section{結 論}

造影剂注入を行った未固定新鮮日本人成人遺体より摘 出した下顎骨 18 体 26 側 (有歯顎 8 体 11 側, 無歯顎 10 体 15 側)を試料として Micro-CT を用いた観察を行い，以 下の結果を得た。

\section{Micro-CT 像の観察}

Micro-CT を用いたことで，下顎管内部での下歯槽動 脈本幹の走行および立ち上がる歯枝を三次元的に再現す ることができた。

\section{2. 下歯槽動脈本幹について}

大臼歯部において，下顎管の上下径に対する下顎管下 壁から下歯槽動脈までの距離の比率は, 有歯顎に対して 無歯顎で大きい值を示す傾向がみられた。下顎管に対す
る下歯槽動脈の水平的位置関係は有歯顎と無歯顎におい て大きな差は認められなかった。下顎管内を走行する下 歯槽動脈本幹の内径は, 有歯顎と比較して無歯顎では細 くなる傾向がみられた。

\section{3. 歯枝について}

歯枝を臼後枝と臼歯に分布する歯枝に分類し，三次元 的に再現することができた。臼後枝は煩舌断面では有歯 顎, 無歯顎とも約 $40^{\circ}$ と煩側方向に分岐していた。また, 臼後枝については有歯顎と無歯顎で大きな差は認められ なかったが，臼歯に分布する歯枝に関しては有歯靧と比 較して無歯顎では歯枝の分岐が少なくなり，歯枝が細く なる傾向がみられた。

稿を終えるにあたり，終始ご懇篤なるご指導とご校閲を賜 りました, 本学解剖学講座主任 井出吉信教授に謹んで敬意を 表するとともに，ご協力いただいた講座各位に深く感謝いた します。

本論文の要旨は, 第 262 回東京歯科大学学会総会 (1997 年 11 月 1 日, 千葉), 第 267 回東京歯科大学学会総会 (1999 年 6 月 5 日, 千葉), 第 25 回日本微小循環学会総会 ( 2000 年 2 月 18 日，横須賀)，第 105 回日本解剖学会総会 (2000 年 3 月 31 日，横浜）において発表した。

\section{文献}

1) Poirot, G., Delattre, J. F., Palot, C. and Flament, J. B. : The inferior alveolar artery in its bony course. Surg. Radiol. Anat. 8 : 237-244, 1986.

2) Zoud, K. and Doran, G. A. : Microsurgical anatomy of the inferior alveolar neurovascular plexus. Surg. Radiol. Anat. 15 : 175-179, 1993.

3）小寺春人, 橋本 㦑：臼後管の一例：管内を走行する 神経・血管について。解剖誌 70:23-30, 1995.

4) Oikarinen, V.J.: The inferior alveolar artery. Suom Hammaslaak Toim 61 : 1-131, 1965.

5）佐志隆士：顎動脈の $\mathrm{X}$ 線解剖。秋田医学 16 : 817-831, 1989.

6) Castelli, W. : Vascular architecture of the human adult mandible. J. Dent. Res. 42: 786-792, 1963.

7) Bradley, J. C. : Age changes in the vascular supply of the mandible. Br. Dent. J. $132: 142-144,1972$.

8) Bradley, J. C. : A radiological investigation into the age changes of the inferior dental artery. Br. J. Oral Surg. $13: 82-90,1975$.

9) Heasman, P. A. and Adamson, J. : An investigation of possible age-related changes in the inferior alveolar artery in man. Br. J. Oral Maxillofac. Surg. 25 : 
406-409, 1987.

10) McGregor, A. D. and MacDonald, D. G. : Age changes in the human inferior alveolar artery: A histological study. Br. J. Oral Maxillofac. Surg. 27 : $371-374,1989$.

11）浦郷篤史, 船越 徹, 佐藤良一：顎動脈硬化症に関す 万研究. 歯基礎誌 $13: 1-13,1971$.

12）浦郷篤史：口腔諸組織の加齢変化：頡骨, 第 1 版, pp. 19-59, クインテッセンス出版, 東京, 1991 .

13）佐藤良一：下歯槽動脈硬化症と歯槽膿漏症. 山口医学 16:73-91, 1967.

14）澤田復治：下顎管の下歯槽動脈に関する研究：特に ラット下䫇管内分布と血管壁構造の生後発育的変化に ついて. 明海歯学誌 $21: 37-57,1992$.

15）加藤久直：下顎管の下歯槽動脈に関する研究：特に正 常構造と放射線照射による影響について，明海歯学誌 20:224-248, 1991 .

16）岸 好彰：血管鋳型法と走査型電顕による内縁上皮直 下の血管網の推移について. 歯基礎誌 24：706-726, 1982 .

17）藤村 朗：ゴールデンハムスターの付着上皮下毛細血 管に関する研究：ゴールデンハムスターとラット，マ ウスとの比較. 歯科学報 87：463-484, 1987.

18）岸 好彰, 高橋和人：口腔粘膜における毛細血管の立 体的観察：歯根膜について. 歯基礎誌 19：192-207, 1977.

19）岩淵 通：歯根膜血管網の立体的観察. 神奈川歯学 $17: 165-184,1982$.

20) Ohta, Y.: Comparative changes in microvasculature and bone during healing of implant and extraction sites. J. Oral Implant. 19 : 184-198, 1993.

21) Shibata, T., Matsumoto, S. and Nagano, T. : Tomograms of the arterial system of the human fetal auditory apparatus obtained by very-high-resolution microfocus $\mathrm{X}$-ray CT and $3 \mathrm{D}$ reconstruction. 解剖 誌 74:545-553, 1999.
22) Bjorndal, L., Carlsen, O., Thuesen, G., Darvann, T. and Kreiborg, S. : External and internal macromorphology in $3 \mathrm{D}$-reconstructed maxillary molars using computerized $\mathrm{X}$-ray microtomography. Int. End. J. $32: 3-9,1999$.

23) Hara, T., Hashimoto, M. and Ide, Y. : Application of micro-CT to the measurement of enamel thickness. 歯基礎誌 $41 ：$ 303-306, 1999.

24) Ito, M., Nakamura, T., Matsumoto, T., Tsurusaki, K. and Hayashi, K. : Analysis of trabecular microarchitecture of human iliac bone using microcomputed tomography in patients with hip arthrosis with or without vertebral fracture. Bone 23 : 163169, 1998.

25）星野 孝, 須賀昭一：顕微 X 線法：Microangiography.（藤井正道，山村武夫 編)，第 1 版, pp. 58-79, 医学書院, 東京, 1970.

26）猪鹿倉兼三：日本人顎動脈の起始, 経過, 分布につい て. 口腔解剖研究 18:91-122, 1961.

27）市川敬一：歯牙喪失による下顎管の位置, 構造および その周囲骨粱構造の変化. 日ロ腔インプラント誌 11： 477-491, 1998.

28) Kingsmill, V. J. and Boyde, A. : Variation in the apparent density of human mandibular bone with age and dental status. J. Anat. 192:233-244, 1998.

29）森田 徹, 竹内修二, 山下 廣：歯の趾失した下顎骨 の形態学的研究. 解剖誌 $68: 316-327,1993$.

30) Neufeld, J. O. : Changes in the trabecular pattern of the mandible following the loss of teeth. J. Prosthet. Dent. 8:685-697, 1958.

31）中島 功：日本人下顎骨の歯牙欠如域における内部構 造に関する研究. 歯科学報 91：419-438, 1991.

32）御手洗 智, 阿部伸一, 井出吉信：歯牙喪失に伴う後 上歯槽動脈の形態変化に関する研究. 日ロ腔インプラ ント誌 13：530-543， 2000. 